\title{
The flora and vegetation of the NE Mediterranean islet with centuries-long human influences
}

\author{
Nenad Jasprica ${ }^{1}$, Katija Dolina ${ }^{1^{*}}$, Milenko Milović ${ }^{2}$ \\ ${ }^{1}$ Institute for Marine and Coastal Research, University of Dubrovnik, P.O. Box 83, HR-20000 Dubrovnik, Croatia \\ 2 "Antun Vrančić" Grammar School, Put Gimnazije 64, HR-22000 Šibenik, Croatia
}

\begin{abstract}
This paper is based on the main results of an analysis of spontaneous flora and vegetation on the small islet of Vrnik $\left(0.281 \mathrm{~km}^{2}\right)$, on which there are some abandoned limestone quarries, on the eastern Adriatic coast. The investigations were carried out from 2014 to 2016. Altogether, 251 vascular plant taxa (species and infraspecific units) were recorded on the islet. A total of 11 plant associations, one subassocation and two stands within 10 vegetation classes were identified. Due to high anthropogenic influences during the last centuries, quarrying in particular, the islet investigated showed a relatively low variety of vascular plant taxa. In addition, clear signs of fragmentation of the forest vegetation were observed.
\end{abstract}

Keywords: Croatia, eastern Adriatic, phytosociology, syntaxonomy, vascular plant diversity

\section{Introduction}

The karstic islet of Vrnik on the eastern Adriatic coast (WGS84: $42^{\circ} 56^{\prime} 9^{\prime \prime} \mathrm{N} 17^{\circ} 10^{\prime} 9^{\prime \prime} \mathrm{E}$; or according to Croatian Terrestrial Reference System 1996 (HTRS96): X=554623, $\mathrm{Y}=4755335$ ) is part of the Korčula Archipelago situated in the channel between the Pelješac peninsula and the island of Korčula in southern Croatia (Fig. 1). The islet is the second largest in the whole Archipelago which comprises 19 islets and five rocks.

Exploitation of mineral resources (architectural building stone) has a long tradition in the Archipelago, including the islet of Vrnik in particular, dating back to the Roman Empire (Krklec et al. 2011). The Senonian limestone was used
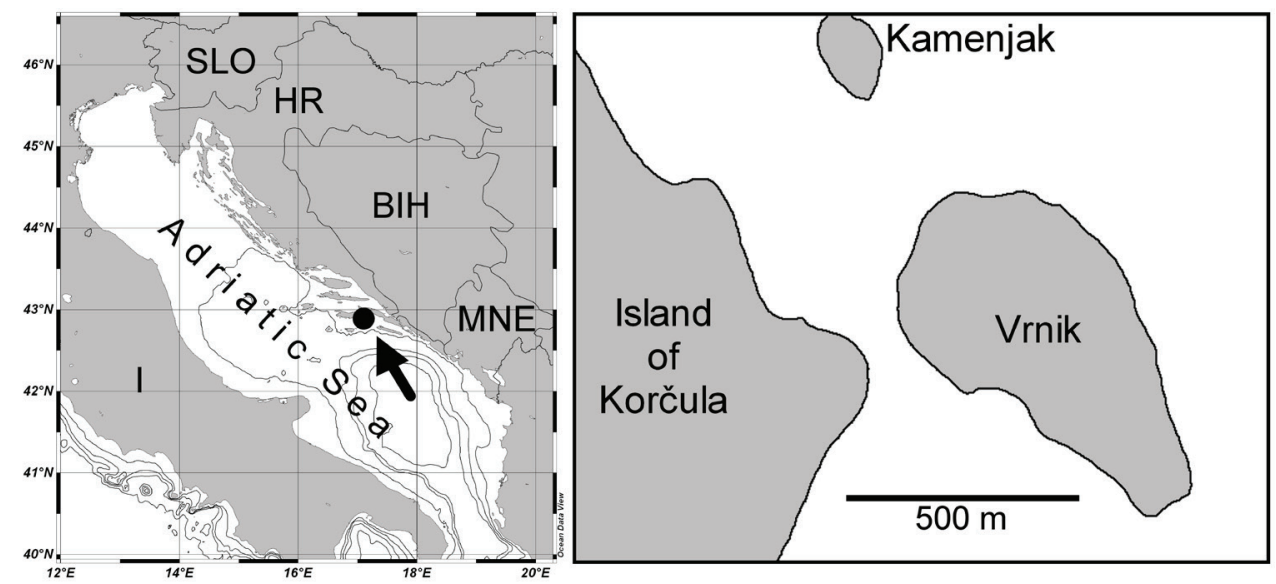

Fig. 1. Geographical position of the islet of Vrnik in south Croatia, eastern Adriatic (Abbreviations: SLO: Slovenia; HR: Croatia; BIH: Bosnia and Herzegovina; MNE: Montenegro; I: Italy).

\footnotetext{
* Corresponding author, e-mail: katija.dolina@unidu.hr
} 
for the construction and decoration of villas and residences in the region of Dalmatia, the city of Dubrovnik in particular, but it was also exported to the Orient (e.g., Constantinople) and Italy (Gjivoje 1969, Krklec et al. 2011). The finding of the Lumbarda Psephisma, the most important monument written in Greek in Croatia, carved into a stone pillar which was found near to the village of Lumbarda on the island of Korčula, suggests that the islet was populated at the beginning of the $4^{\text {th }}$ or $3^{\text {rd }}$ century BC (Kršinić-Šove 1971, Solarić and Solarić 2009). During the last six centuries or so around six hundred people lived there and worked in thirty quarries (Dunda et al. 2003). Quarrying on the island continued until the late 1950s and cessation of it coincides with the depopulation of the island (Galić et al. 1999). The population in the middle of the $20^{\text {th }}$ century was almost 200 ; numbers then gradually diminished and nowadays there are only a few permanent inhabitants. Nowadays, it is very popular as a tourist destination in the summer time having a population in excess of about 200 people in a very small settlement (the village of Vrnik). The modern village of Vrnik occupies the land between the quarry-face and the northern coast, an area previously quarried away. Abandoned quarry workers' cottages cluster in the eastern part of the modern village.

In the Mediterranean Basin the flora of small and very small islands has long been a subject of interest in relation both to basic floristic knowledge and also in order to assess the impact of land use on the land cover (Jasprica et al. 2015, and references therein). In the northern section of the Mediterranean Sea, the Adriatic basin forms its most important part. The Adriatic Sea has over 1,300 islands and isles, mostly located along its eastern, Croatian, coast, which are considered among the most diverse in the Mediterranean region. Generally, the Dalmatian coast could be also defined as a hotspot, but the data on its flora are still incomplete (Médail and Quézel 1997). An estimation using the species-area relationship analysis (SAR) for 106 Adriatic islands (Nikolić et al. 2008), shows that 1,807 plant taxa grow on the Croatian islands, providing a heritage of biodiversity that must be bequeathed to future generations as a 'reservoir' available for the processes of biological evolution and for their ecological value. However, there naturally remain islands and islets that have not yet been floristically and ecologically investigated.

Generally, all islets in the Korčula Archipelago remain completely botanically unknown, and only a few botanical studies have been made of the rest of the islets (e.g. Bogdanović and Brullo 2015, Jasprica and Milović 2016). The aim of this study was to present results of investigations into the flora and vegetation of the islet of Vrnik. Our hypothesis was that vegetation cover on the islet is mostly the result of temporary natural factors.

\section{Study area}

The islet has an area of $0.281 \mathrm{~km}^{2}$ with a maximum length of 900 meters, a width of $450 \mathrm{~m}$, a maximum altitude of 46 $\mathrm{m}$ and a distance from the island of Korčula of $100 \mathrm{~m}$ (Fig. 1). The predominant soil type is calcocambisol (Korolija et al. 1977). The coast is low and rocky and has a total length of $2.3 \mathrm{~km}$. Sea depths around the islet are between 2 and $15 \mathrm{~m}$.

Quarrying activity was focused at the northern part of the islet (Fig. 2). A near continuous quarry face runs across this area for just over $500 \mathrm{~m}$ from midway along the northeast side of the islet to midway along its northwest side; a second quarry-face runs from this point down the western side of the islet for at least $250 \mathrm{~m}$ (Russell and Glicksman 2015).

The climate of the islet is Mediterranean, with mild winters and hot summers. The reference thermo-pluviometric station is Korčula. The average annual air temperature is 16.8 ${ }^{\circ} \mathrm{C}$, precipitation ranges from $1000-1250 \mathrm{~mm} \mathrm{yr}^{-1}$ and there are 2,400 hours of sunshine a year (Krklec et al. 2011). Overall the bioclimate of the area can be defined as lower mesoMediterranean (sensu Rivas-Martínez et al. 2011, Jasprica and Milović 2016).

The islet belongs, as a part of the island of Korčula, to the Important Plant Areas (IPAs) in Croatia (Jasprica 2010). In addition, the islet is part of the NATURA 2000 European Ecological Network of sites important for birds (site code HR1000036: Middle Dalmatian islands and the Pelješac peninsula; Official Gazette of the Republic of Croatia 2013b, 2015). Unfortunately, there are currently no plans for Natura 2000 network management of the islet.

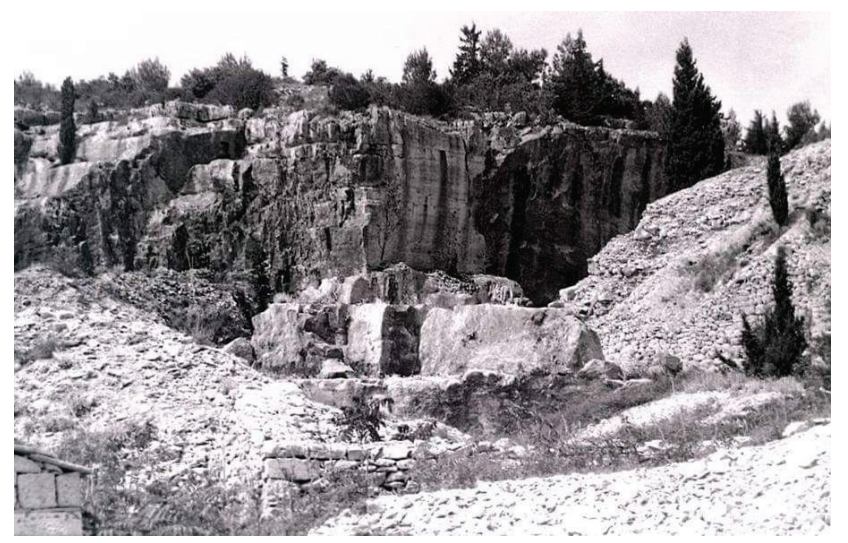

Fig. 2. Quarry-face on the northern side of the islet of Vrnik in the late 1950s.

\section{Materials and methods}

\section{Flora}

The study was carried out from 2014 to 2016 in different seasons (early and late spring, early summer and autumn). Herbarium specimens are deposited in the herbarium collection of the Laboratory for Terrestrial Flora and Fauna of the University of Dubrovnik (www.imp-du.com). Collections were made only if ten or more individuals were present in a plant population. Coordinates were listed according to the Croatian Terrestrial Reference System 1996 (HTRS96) based on the European Terrestrial Reference System 1989 (ETRS89) with Geodetic Reference System 1980 (GRS80) level-ellip- 
soid as a mathematical and physical approximation of Earth's shape.

Data on the surface area and perimeter of the islands were obtained from the Croatian Programme for the protection and use of small, both inhabited and uninhabited, islands and the surrounding sea (Ministry of the Sea, Transport and Infrastructure 2007). The highest altitude was determined using topographic maps to the scale 1:25000 (TK25, TOPO HR). In the list (On-line Suppl. Tab. 1), species are given in alphabetical order. For each taxon, life form and chorological element are reported. The life form follows the Raunkiaer system (Raunkiaer 1934) as proposed by Pignatti (1982). Regarding chorological form, reference was made to Jasprica et al. (2016a), Milović et al. (2016) and references therein. Taxonomic nomenclature follows the Flora Croatica Database (Nikolić 2017).

Tab. 1. Life-form spectra on the islet of Vrnik.

\begin{tabular}{lc}
\hline Life forms & No. (\%) \\
\hline Therophytes (T) & $89(35.4)$ \\
Hemicryptophytes (H) & $60(23.9)$ \\
Phanerophytes (P) & $49(19.5)$ \\
Chamaephytes (Ch) & $27(10.8)$ \\
Geophytes (G) & $25(10.0)$ \\
Hydrophytes (Hy) & $1(0.4)$ \\
Total taxa & $251(100.0)$ \\
\hline
\end{tabular}

Taxa listed in the Red Book of Vascular Flora of Croatia (Nikolić and Topić 2005, Nikolić 2017) are marked with their corresponding IUCN status (IUCN 2016). Taxa considered to be endemic are denoted according to Nikolić et al. (2015). In addition, strictly protected taxa (SPT) as defined by Croatian law are also denoted (Official Gazette of the Republic of Croatia 2013a, c). Any invasive alien taxa (IAS) have been defined according to Nikolić et al. (2014) and Nikolić (2017).

Taxa were determined using the standard determination keys, books and guides: Bonnier (1911-1935), Fiori (19231929), Hayek (1924-1933), Hegi (1936-1987), Horvatić and Trinajstić (1967-1981), Tutin et al. (1968-1980, 1993), Javorka and Csapody (1975), Trinajstić (1975-1986), Pignatti (1982), Delforge $(1995,2006)$, etc.

\section{Vegetation}

Vegetation was studied in accordance with the principles of the Braun-Blanquet approach (Braun-Blanquet 1964), adopting the International Code of Phytosociological Nomenclature (Weber et al. 2000, see also Dengler et al. 2008). Altogether, 26 phytosociological relevés were collected on the islets. The plot size used to sample vegetation was established so as to represent the full floristic composition, depending on plant density and homogeneity of vegetation cover. Geographical coordinates using the Croatian Terrestrial Reference System 1996 (HTRS96), elevation above sea level, aspect and slope inclination were noted for each relevé. The relevés were separated into associations/stands on the basis of the diagnostic and/or dominant species, in line with the traditional syntaxonomic system of the communities. The syntaxonomical system (the EuroVegChecklist) proposed by Mucina et al. (2016), and followed by Škvorc et al. (2017) was applied. Classification of the vegetation units distinguished into habitat types of Annex I of the Habitats Directive 92/43/EEC was made according to the List of NATURA 2000 habitats declared by the Croatian Government (European Commission 1992, 2013; Official Gazette of the Republic of Croatia 2014). Priority habitats are denoted by an asterisk $\left(^{*}\right)$ as shown in the syntaxonomic scheme.

\section{Results}

\section{Flora}

Two hundred and fifty-one (251) vascular plant taxa (species and infraspecific units) were recorded on the islet of Vrnik (On-line Suppl. Tab. 1). Altogether, 70 families and 186 genera were noted. Among them, the families most represented were: Poaceae (30 taxa, 12\%), Fabaceae (28, 11.2\%), Cichoriaceae (16, 6.4\%), Asteraceae (13, 5.2\%), Lamiaceae (11, 4.4\%), Rubiaceae and Caryophyllaceae (eight taxa in each, 3.2\%), and Apiaceae, Brassicaceae, Euphorbiaceae and Ranunculaceae (six taxa in each, 2.4\%). Four taxa can be considered as endemic: Anthyllis vulneraria ssp. weldeniana, Limonium dictyophorum, Lolium subulatum and Seseli tomentosum.

From the Croatian Red List, Papaver hybridum is considered to be a Critically Endangered (CR) taxon. Endangered taxa (EN) were Carex extensa, Delphinium staphisagria and Glaucium flavum, while Ophrys sphegodes, Orchis simia, Parapholis incurva and Salsola soda have been classified as Vulnerable (VU). In addition, nine taxa (Adiantum capillusveneris, Anacamptis pyramidalis, Cyclamen repandum, Elymus pycnanthus, Limonium dictyophorum, Matthiola incana, Seseli tomentosum, Sternbergia lutea and Teucrium fruticans) were classified as Near Threatened (NT). Ruscus aculeatus was found to be of Least Concern (LC). Seven taxa (Brachypodium phoenicoides, Ecballium elaterium, Echinaria capitata, Lolium subulatum, Raphanus raphanistrum ssp. landra, Trifolium echinatum and Posidonia oceanica) have been classified as Data Deficient (DD).

In total, 16 taxa were Strictly Protected (SPT) by Croatian law: Anacamptis pyramidalis, Anthyllis vulneraria ssp. weldeniana, Carex extensa, Delphinium staphisagria, Echinaria capitata, Gladiolus illyricus, Glaucium flavum, Limonium dictyophorum, Lolium subulatum, Ophrys sphegodes, Orchis simia, Papaver hybridum, Parapholis incurva, Posidonia oceanica, Salsola soda and Seseli tomentosum.

Among the recorded taxa, Ailanthus altissima, Carpobrotus acinaciformis, Conyza canadensis and C. sumatrensis are considered to be invasive (IAS). Carpobrotus acinaciformis covers larger areas on the northern slopes of the islet.

The analysis of plant life forms showed that the Vrnik flora is dominated by therophytes (35.4\%) and hemicryptophytes (23.9\%), respectively (Tab. 1 ). 
The Mediterranean floral element (60.6\%), followed by a considerable proportion of South European plants (15.5\%) and Cosmopolitans (13.1\%), dominated on the islet (Tab. 2).

Tab. 2. Floral elements on the islet of Vrnik.

\begin{tabular}{lc}
\hline Floral elements & No. $(\%)$ \\
\hline Mediterranean (MED) & $152(60.6)$ \\
South European (SEU) & $39(15.5)$ \\
Cosmopolitan (WISP) & $33(13.1)$ \\
Eurasian (EUAS) & $13(5.2)$ \\
European (EURO) & $6(2.4)$ \\
Cultivated and adventive plants (CUAD) & $6(2.4)$ \\
Illyrian-Balkanic (ILBA) & $1(0.4)$ \\
Southeast European (SEEU) & $1(0.4)$ \\
Total taxa & $251(100.0)$ \\
\hline
\end{tabular}

\section{Vegetation}

In all, 11 plant associations, one subassocation and two stands within 10 vegetation classes were identified on the islet. These communities are described below and discussed in the same order of the syntaxonomical scheme.

Their syntaxonomic scheme is as follows (corresponding NATURA 2000 habitat codes are added in square brackets):

PHRAGMITO-MAGNOCARICETEA Klika in Klika et Novák 1941

OENANTHETALIA AQUATICAE Hejný ex BalátováTuláčková et al. 1993 1964

Eleocharito palustris-Sagittarion sagittifoliae Passarge

Eleocharitetum palustris Savič 1926

ZOSTERETEA Pignatti 1953

POSIDONIETALIA OCEANICAE Den Hartog ex Mucina in Mucina et al. 2016

Posidonion oceanicae Br.-Bl. ex Molinier 1960

Posidonietum oceanicae (Funk 1927) Molinier 1958 [habitat code $1120^{\star}$ - Posidonia beds (Posidonion oceanicae)]

CAKILETEA MARITIMAE Tx. et Preising in Tx. ex Oberd. 1952

THERO-ATRIPLICETALIA Pignatti 1953

Euphorbion peplidis Tx. ex Oberd. 1952

Euphorbio pineae-Glaucietum flavi Horvatić 1934 [habitat code 1210 - Annual vegetation of drift lines (Euphorbion peplidis)]

CRITHMO-STATICETEA Br.-Bl. in Br.-Bl. et al. 1952 CRITHMO-STATICETALIA Molinier 1934

Limonion anfracti-cancellati (Horvatić 1934) Mucina in Mucina et al. 2016
Limonietum anfracti Ilijanić and S. Hećimović 1982 helichrysetosum italici Jasprica 2015 [habitat code 1240 - Vegetated sea cliffs of the Mediterranean coasts with endemic Limonium spp.]

SAGINETEA MARITIMAE Westhoff et al. 1962

Parapholis incurva community [habitat code 1310 - Salicornia and other annuals colonising mud and sand]

CYMBALARIO-PARIETARIETEA DIFFUSAE Oberd. 1969

TORTULO-CYMBALARIETALIA Segal 1969

Galio valantiae-Parietarion judaicae Rivas-Mart. ex O. de Bolòs 1967

Oxalido-Parietarietum judaicae (Br.-Bl. 1952) Segal 1969

Cymbalario-Asplenion Segal 1969

Linario cymbalariae-Parietarietum ramiflorae Pignatti 1952 (=Cymbalarietum muralis Görs 1966) [habitat code 8210 - Calcareous rocky slopes with chasmophyic vegetation]

LYGEO SPARTI-STIPETEA TENACISSIMAE RivasMart. 1978 nom. conserv. propos. (=THERO-BRACHYPODIETEA RAMOSI Br.-Bl. in Br.-Bl. et al. 1947)

CYMBOPOGONO -BRACHYPODIETALIA RAMOSI Horvatić 1963

Cymbopogono-Brachypodion ramosi Horvatić 1963

Piptatheretum miliaceae Horvatić (1956) 1958 [habitat code $6220^{*}$ - Pseudosteppe with grasses and annuals TheroBrachypodietea]

PAPAVERETEA RHOEADIS S. Brullo et al. 2001 nom. conserv. propos.

APERETALIA SPICAE-VENTI J.Tx. et Tx. in Malato-Beliz et al. 1960 nom. conserv. propos.

Cynodon dactylon community

CHENOPODIETEA Br.-Bl. in Br.-Bl. et al. 1952

BROMETALIA RUBENTI-TECTORUM (Rivas Goday et Rivas-Mart. 1973) Rivas-Mart. et Izco 1977 nom. conserv. propos.

Hordeion murini Br.-Bl. in Br.-Bl. et al. 1936

Hordeetum leporini Br.-Bl. 1936

QUERCETEA ILICIS Br.-Bl. ex A. Bolòs et O. de Bolòs in A. Bolòs y Vayreda 1950

PINETALIA HALEPENSIS Biondi, Blasi, Galdenzi, Pesaresi et Vagge in Biondi et al. 2014

Pistacio lentisci-Pinion halepensis Biondi, Blasi, Galdenzi, Pesaresi et Vagge in Biondi et al. 2014

Pistacio lentisci-Pinetum halepensis De Marco, Veri et Caneva 1984

Querco ilicis-Pinetum halepensis Loisel 1971 [habitat code 9540 - Mediterranean pine forests with endemic Mesogean pines]

PISTACIO LENTISCI-RHAMNETALIA ALATERNI Rivas-Mart. 1975 
Oleo-Ceratonion siliquae Br.-Bl. ex Guinochet et Drouineau 1944

Myrto communis-Pistacietum lentisci (Molinier 1954) Rivas-Mart. 1975

Erico manipuliflorae-Calicotometum infestae Horvatić 1958 [habitat code 9320 - Olea and Ceratonia forests]

\section{Short description of the associations and stands}

Eleocharitetum palustris Savič 1926. This monospecific or species-poor community develops in small standing water bodies, e.g. shallow depressions with water depths of 10-50 $\mathrm{cm}$, which are fed by rainfall (Fig. 3). These habitats remain slightly wet in summer, but in some years the community can also survive periods of soil desiccation (e.g. Šumberová 2011). In the case of Vrnik, Eleocharis palustris (5) formed stands with the co-occurrence of Chara vulgaris (1) [Rel.: 15.6.2016., HTRS96 X=554620, $Y=4755266$, plot size $16 \mathrm{~m}^{2}$, altitude $40 \mathrm{~m}$, vegetation cover 100\%]. The association has also been reported for the Continental and Mediterranean regions of Croatia (Stančić 2008), other parts of the Balkans (Tzonev et al. 2009, Šilc and Čarni 2012, Laketić et al. 2013), and also in Central and south Europe (Šumberová 2011, Landucci et al. 2013).

Posidonietum oceanicae (Funk 1927) Molinier 1958. It occurs on various stations around the islet and develops on the moving seabed in depths between 1 and $15 \mathrm{~m}$, and represents the breeding site for many species. Extensive descriptions of the structure and the functioning of Posidonia beds have been produced by Buia et al. (2000) and Den Hartog (2003).

Euphorbio pineae-Glaucietum flavi Horvatić 1934 (Online Suppl. Tab. 2, rels. 1-2). On the islet of Vrnik this is represented by the therophytic halo-nitrophilous vegetation that has colonised the sandy pebbled beach, rich in organic matter. The association is very common along the whole eastern Adriatic in the mid-littoral zone on sandy and gravel substrates (Horvatić 1963, Jasprica et al. 2016b).

Limonietum anfracti Ilijanić and S. Hećimović 1982 helichrysetosum italici Jasprica 2015 (On-line Suppl. Tab. 2, rels.

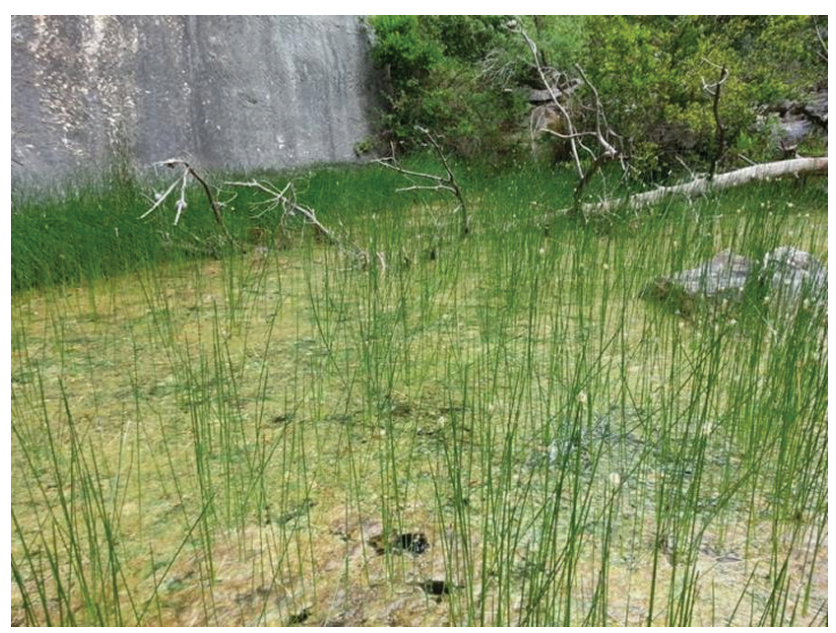

Fig. 3. Eleocharitetum palustris Savič 1926.
3-7). The rocky shores are home to the Limonietum anfracti plant association, characterised by Limonium dictyophorum, a species endemic to the southern coast of the eastern Adriatic (Nikolić et al. 2015), which forms dense low-spreading formations that colonise the cracks in the rocks.

Parapholis incurva community. [Rel.: 15.6.2016., HTRS96 $\mathrm{X}=554795, \mathrm{Y}=4755453$, plot size $6 \mathrm{~m}^{2}$, altitude $1 \mathrm{~m}$, vegetation cover $70 \%]$. This therophytic community is rare on the islet and it occurs within the village at sunny sites at the edge of paths. Soils are very dry, usually with a sand admixture. In the case of Vrnik, the floristic composition was as follows: Parapholis incurva (4), Dorycnium hirsutum (+), Cakile maritima (+), Silene vulgaris ssp. angustifolia (1), Helichrysum italicum (+), Pinus halepensis (r), Anagalis arvensis (+), Ailanthus altissima (r).

On the islet wall vegetation was only found at a few sites within the village. The association Oxalido-Parietarietum judaicae (On-line Suppl. Tab. 3, rels. 1-3) is a sciaphilous and nitrophilous association mainly occurring on $\mathrm{N}$-facing or shady walls (Brullo and Guarino 1998). In its typical aspect it forms a belt in the lower part of the wall. The presence of Scaligeria cretica (=S. napiformis), a rare taxon of Croatian flora, expands our knowledge of its chorology on the eastern Adriatic (Skelin et al. 2014). In the Linario cymbalariaeParietarietum ramiflorae (On-line Suppl. Tab. 3, rel. 4), Cymbalaria muralis contributed significantly. Additionally, quarry faces are covered with Inula verbascifolia, Adianthum capillusveneris, Pinus halepensis, Cupressus horizontalis, Calamintha nepetoides and Hedera helix (On-line Suppl. 3, rels. 5-6). The thermophilic chasmophytic vegetation of the Asplenietea trichomanis class, at least in part, is not developed on the islet.

Piptatheretum miliaceae Horvatić (1956) 1958. [Rel.: 15.6.2016., HTRS96 X=554334, 4755425, plot size $8 \mathrm{~m}^{2}$, altitude $1 \mathrm{~m}$, vegetation cover $100 \%$ ]. This association is rare and mostly localized on sites within the village, and sporadically on deep and wet soil within Aleppo pine wood. The floristic composition on the islet was as follows: Pipatherum miliaceum (5), Verbascum sinuatum (1), Calamintha nepetoides (+), Conyza sumatrensis $(+)$, Lagurus ovatus $(+)$, Lavatera arborea $(+)$, Asphodelus fistulosus (+), Parietaria judaica (+), Euphorbia peplus (+), Rubia peregrina (+), Ailanthus altissima (+), Hedera helix $(+)$, Bituminaria bituminosa $(+)$, Sonchus asper ssp. glaucescens (+), Geranium sp. (+).

Cynodon dactylon community. [Rel.: 15.6.2016., HTRS96 $\mathrm{X}=554367,4755533$, plot size $12 \mathrm{~m}^{2}$, altitude $1 \mathrm{~m}$, vegetation cover $90 \%$ ]. It occurs at trampled sites with sandy dry soils in the village. The floristic composition on the islet was as follows: Cynodon dactylon (5), Hordeum murinum ssp. leporinum (1), Silene vulgaris ssp. angustifolia (1), Melilotus officinalis (1), Trifolium scabrum (+), Galium lucidum (+), Medicago truncatula (+), Anthemis arvensis $(+)$, Arenaria leptoclados $(+)$, Desmazeria rigida $(+)$, Lophochloa cristata $(+)$, Lagurus ovatus (+), Lolium perenne (+), Malva sylvestris (+), Spergularia salina $(+)$.

Hordeetum leporini Br.-Bl. 1936. This nitrophilous vegetation occurs in sunny sites at the edge of paths or on aban- 
doned land where the soil formation is embryonic and human disturbance is a significant factor. It is characterized by species of predominantly annual spring development. The floristic composition on the islet [Rel.: 26.4.2014., HTRS96 $\mathrm{X}=554369, \mathrm{Y}=4755536$, plot size $25 \mathrm{~m}^{2}$, altitude $1 \mathrm{~m}$, vegetation cover 90\%] was as follows: Hordeum murinum ssp. leporinum (2), Malva sylvestris (+), Plantago coronopus (1), Anthemis arvensis (1), Bromus madritensis (+), Bromus racemosus (+), Carduus pycnocephalus (+), Crepis rubra (+), Euphorbia helioscopia $(+)$, Galium aparine $(+)$, Geranium molle $(+)$, Lagurus ovatus (+), Medicago polymorpha (+), Melilotus officinalis (3), Mercurialis annua (+), Rhagadiolus stellatus (+), Setaria viridis (+), Sonchus oleraceus (+), Trifolium tomentosum $(+)$. The association has already been noted for ruderal sites of the eastern and western Adriatic coasts and also reported for the W. Mediterranean (Jasprica et al. 2016b, and references therein).

Among the wood vegetation, Querco-Pinetum halepensis occupies the majority of the area of the islet of Vrnik with a vegetation cover of $90-100 \%$. It occurs exclusively on the southern slopes. It has value from an aesthetic and ecological point of view (On-line Suppl. Tab. 4, rels. 9-13). Quercus ilex is developed in the brush layer and Pinus halepensis is the dominant taxon. By contrast, Pistacio-Pinetum halepensis develops on the eastern and south-eastern part of the islet, where Pistacia lentiscus contributes significantly (On-line Suppl. Tab. 4, rels. 5-8). Among macchia, the Myrto-Pistacietum association has developed as low (mostly between 1 and $1.5 \mathrm{~m}$ ) and dense shrub formations, and forms a strip between halophytic vegetation and the islet's central area (Online Suppl. Tab. 4, rels. 1-3). The Erico-Calicotometum, with a height of 3-4 m, occupies a very limited surface area on the southern side of the islet, and has the greatest number of taxa (On-line Suppl. Tab. 4, rel. 4). In general most of the companions of these associations were treated as characteristic species of the Festuco-Brometea and Lygeo-Stipetea classes. Among companions, Brachypodium retusum has the highest frequency.

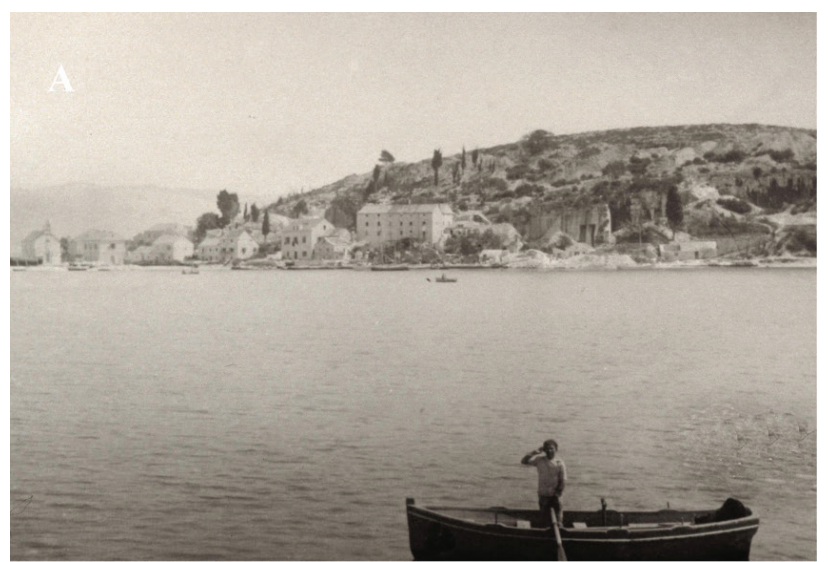

\section{Discussion}

The predominance of the Poaceae, Cichoriaceae, Asterace$a e$ and Fabaceae families, a clear dominance of therophytes in the life-form spectrum and the Mediterraneans in the chorological spectrum include the islet in the Mediterranean context. The presence of the endemic taxa and those occurring in the national Red List, including strictly protected flora, confirm the peculiarity of the surveyed area from the phytogeographic point of view (Nikolić et al. 2008).

The islet investigated showed a relatively low variety of vascular plant taxa. This is, at least partly, in accordance with the findings of Pandža and Milović (2015) for some uninhabited eastern Adriatic islets with surface areas of less than one $\mathrm{km}^{2}$. However, the differences in the floristic diversity among the islets are very difficult to evaluate due to variations in the topography and the degree of human presence on the islets (Pasta et al. 2014, Jasprica et al. 2016b, and references therein). In general, this is not a rare pattern on such islets, which often represent 'unbalanced biota' (Jasprica et al. 2015).

The currently low number of alien species to be found in the islet may be related to the low level of human activity. However, habitat modification or space occupation by Carpobrotus acinaciformis might represent a threat (Brundu 2013, Celesti-Grapow et al. 2016). The risk of invasion may increase if more species are directly introduced to the islet, and if anthropogenic disturbance and a changing climate make conditions more favourable for alien species (Lloret et al. 2005, Pretto et al. 2012, Cardona Pons et al. 2013, Valaoras 2014).

Nevertheless, quarrying operations caused ecosystem disturbance and profound modifications of the substratum and the topographical profile of the islet (Khater and Arnaud 2007). In our case, fragmentation of the forest vegetation was observed. Parts of the open quarry-faces have become overgrown during the last few decades (Fig. 4), and, in general, on such heavily disturbed areas, spontaneous colonization is slow (Whisenant et al. 1995). This survey revealed the presence on quarry cliffs of 'true' rupicolous species (e.g. Campanula pyramidalis, etc.), which have been recorded for

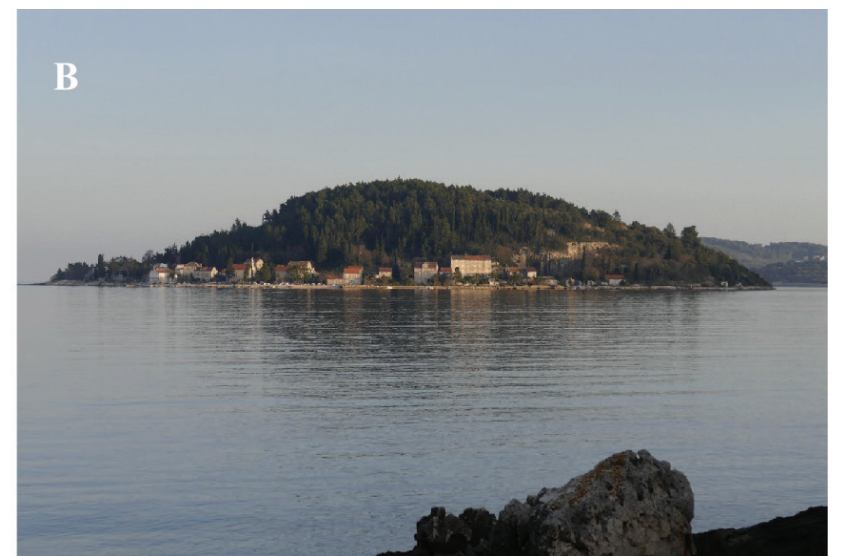

Fig. 4. Vegetation cover on the islet during the Second World War (A) and in 2016 (B). 
the neighbouring islet (Jasprica and Milović 2016). Generally, the scientific literature lacks suitable references highlighting the ecological value of abandoned quarries. Arnal (1993) and Vela (2002) confirmed the presence in quarries of particular plant species, some of them being exclusive to this type of ecosystem and some rare and/or protected species spotted in abandoned quarries have been reported beyond their natural distribution area. These were not found in our case.

Regarding vegetation, the islet shows a relatively low variety of terrestrial plant associations, and most of these are fragmentary. However, some of them (e.g. Parapholis incurva and Cynodon dactylon communities) are little known on the eastern Adriatic and further comparable research is required for a more complete understanding of these stands.

In conclusion, we confirm our hypothesis that the vegetation cover on the islet is in general a result of temporary natural factors. However, the environmental impact from past quarrying activities is observable. The study also emphasizes the importance of continuous floristic and phytosociological investigations on the Croatian islands and islets, as local and foreign authors have done for other sites in the Adriatic Basin and in some other Mediterranean countries. Eight habitattypes have been included in the 92/43/EEC Directive Annex I. We wish to stress that these habitats deserve correct management which should be grounded on a deep knowledge on the Croatian island and islets.

\section{Acknowledgements}

The authors thank Smiljana Matijaca, Nebojša Jeričević and Neven Fazinić for providing the photographs (Figs. 2 and $4 \mathrm{~A}, \mathrm{~B}$ ), Steve Latham (UK) for improving the English, and two anonymous reviewers whose observations improved the quality of the final version of the manuscript. Thanks also are extended to Milka Batistić, Mirjana Jeričević and Nebojša Jeričević for their support during the feld research, and Dr Rade Garić for drawing Figure 1.

\section{References}

Arnal, M. G., 1993: La reconquête par la végétation spontanée des carrières de Fontainebleau. Approche de la dynamique végétale. Recommandation pour une valorisation écologique. L'aménagement et la réhabilitation écologique des carrières sèches. Association Francaise des Ingénieurs Ecologues, Beaune.

Bogdanović, S., Brullo, S., 2015: Taxonomic revision of the Limonium cancellatum group (Plumbaginaceae) in Croatia. Phytotaxa 215, 1-87.

Bonnier, G., 1911-1935: Flore compléte illustrée en couleurs de France, Suisse et Belgiqe. Delachaux et Niestlé, Neuchâtel; Librairie Générale de l'Enseignement, Paris; J. Lebègue et Cie, Bruxelles.

Braun-Blanquet, J., 1964: Pflanzensoziologie. Grundzüge der Vegetationskunde. Springer-Verlag, New York.

Brullo, S., Guarino, R., 1998: Syntaxonomy of the Parietarietea judaicae class in Europe. Annali di Botanica 56, 109-146.

Brundu, G., 2013: Invasive alien plants in protected areas in Mediterranean islands: Knowledge gaps and main threats. In: Foxcroft, L. C., Pyšek, P., Richardson, D. M., Genovesi, P. (eds.), Plant invasions in protected areas. Patterns, problems and challenges, 395-422. Springer, Dordrecht.

Buia, M. C., Gambi, M. C., Zupo, V., 2000: Structure and functioning of Mediterranean seagrass ecosystem: an overview. Biologia Marina Mediterranea 7, 167-190.

Cardona Pons, E., Estaún Clarisó, I., Comas Casademont, M., Fraga i Arguimbau, P. (eds.), 2013: $2^{\text {nd }}$ Botanical Conference in Menorca. Proceedings and abstracts. Islands and plants: preservation and understanding of flora on Mediterranean islands. Col lecció Recerca 20. Institut Menorquí d’Estudis i Consell Insular de Menorca, Maó.

Celesti-Grapow, L., Bassi, L., Brundu, G., Camarda, I., Carli, E., D’Auria, G., et al., 2016: Plant invasions on small Mediterranean islands: An overview. Plant Biosystems 150, 1119-1133.

Delforge, P., 1995: Orchids of Britain and Europe. Harper Collins Publishers, London.

Delforge, P., 2006: Orchids of Europe, North Africa and the Middle East ( $3^{\text {rd }}$ ed.). A. \& C. Black, London.

Den Hartog, C., 2003: Phytosociological classification of seagrass communities. Phytocoenologia 33, 203-229.
Dengler, J., Chytry, M., Ewald, J., 2008: Phytosociology. In: Jørgensen, S. E., Fath, B. D. (eds.), Encyclopedia of Ecology, 2767-2779. Elsevier, Oxford.

Dunda, S., Kujundžić, T., Globan, M., Matošin, V., 2003: Architectural-building stone exploitation. Rudarsko-geološko-naftni fakultet Sveučilišta u Zagrebu, Zagreb. Retrieved October 1, 2016 from http://rgn.hr/ tkorman/nids_tkorman/ Kamen/ knjiga.html (in Croatian).

European Commission, 1992: Council Directive 92/43/EEC of 21 May 1992 on the conservation of natural habitats and of wild fauna and flora. Retrieved October 6, 2016 from http://eur-lex.europa.eu/legal-content/EN/TXT/ $\mathrm{PDF} /$ ?uri=CELEX:31992L0043\& from=EN.

European Commission, 2013: Interpretation Manual of European Union Habitats - EUR28. April 2013. Retrieved October 6, 2016 from http://ec.europa.eu/environment/nature /legislation/habitatsdirective/docs/Int_Manual_EU28.pdf.

Fiori, A., 1923-1929: La Nuova Flora Analitica d'Italia 1-2. Tipografia di M. Ricci, Firenze.

Galić, I., Zorić, I., Krasić, O., Krsnik, D., 1999: Capital mining project of architectual-building stone excavation in stone quarry "Vrnik". Elaborat. Ministarstvo gospodarstva, rada i poduzetništva RH, Zagreb (in Croatian).

Gjivoje, M., 1969: Island of Korčula. Prosvjeta, Zagreb (in Croatian).

Hayek, A., 1924-1933: Prodromus florae Peninsulae Balcanicae 1-3. Dahlem bei Berlin.

Hegi, G., 1936-1987: Illustrierte Flora von Mitteleuropa. Carl Hanser Verlag, München.

Horvatić S., 1963: Vegetation map of the island of Pag with survey of the plant communities of Hrvatsko Primorje. Prirodoslovna istraživanja 33 Acta Biologica 4, 1-187 (in Croatian).

Horvatić, S., Trinajstić, I. (eds.), 1967-1981: Analytical flora of Yugoslavia 1. Šumarski fakultet, Sveučilišna naklada Liber, Zagreb (in Croatian).

IUCN, 2016: Guidelines for Using the IUCN Red List Categories and Criteria. Version 12. Prepared by the Standards and Petitions Subcommittee. Retrieved October 6, 2016 from http:// www.iucnredlist.org/documents/RedListGuidelines.pdf. 
Jasprica, N., 2010: Korčula. In: Nikolić, T., Topić J., Vuković, N. (eds.), Important Plant Areas in Croatia, 192-197. Prirodoslovno-matematički fakultet Sveučilišta u Zagrebu, Školska knjiga d.o.o, Zagreb (in Croatian).

Jasprica, N., Dolina, K., Milović, M., 2015: Plant taxa and communities on three islets in south Croatia, NE Mediterranean. Natura Croatica 24, 191-213.

Jasprica, N., Milović, M., 2016: The vegetation of the islet of Badija (south Croatia), with some notes on its flora. Natura Croatica $25,1-24$.

Jasprica, N., Bogdanović, S., Dolina, K., Ruščić, M., Pandža, M., Kovačić, S., 2016a: Syntaxonomy of Arundo stands along the eastern Adriatic coast. Plant Biosystems 150, 887-903.

Jasprica, N., Milović, M., Kovačić, S., Stamenković, V., 2016b: Phytocoenotic diversity of the NE-Adriatic island of Olib. Plant Sociology 53, 53-78.

Javorka, S., Csapody, V., 1975: Iconographia florae partis austroorientalis Europae centralis. Akadémiai Kiadó, Budapest.

Khater, C., Arnaud, M., 2007: Application of restoration ecology principles to the practice of limestone quarry, rehabilitation in Lebanon. Lebanese Science Journal 8, 19-28.

Korolija, B., Borović, I., Grimani, I., Marinčić, S., Jagačić, T., Magaš, N., Milanović, M., 1977: Basic Geological Map of SFRY 1:100000, Geology of the Lastovo K33-46, Korčula K33-47 and Palagruža K33-57 sheets. Institut za geološka istraživanja, Zagreb, Savezni geološki zavod, Beograd (in Croatian).

Krklec, K., Ljubenkov, I., Bensa, A., 2011: The natural resources of the island of Korčula. Geoadria 16, 3-25 (in Croatian).

Kršinić-Šove, F., 1971: The discovery of new fragments of the Greek inscription from Lumbarda on the island of Korčula. Vjesnik Arheološkog muzeja u Zagrebu 4, 119-120 (in Croatian).

Laketić, D. Lj., 2013: Phytocoenological classification of lake vegetation in Serbia. PhD Thesis. Faculty of Biology, University of Belgrade, Belgrade (in Serbian).

Landucci, F., Gigante, D., Venanzoni, R., Chytrý, M., 2013: Wetland vegetation of the class Phragmito-Magno-Caricetea in central Italy. Phytocoenologia 43, 67-100.

Lloret, F., Medail, F., Brundu, G., Camarda, I., Moragues, E., Rita, J., Lambdon, P., Hulme, P. E., 2005: Species attributes and invasion success by alien plants on Mediterranean islands. Journal of Ecology 93, 512-520.

Médail, F., Quézel, P., 1997: Hot-spots analysis for conservation of plant biodiversity in the Mediterranean basin. Annals of the Missouri Botanical Garden 84, 112-127.

Milović, M., Kovačić, S., Jasprica, N., Stamenković, V., 2016: Contribution to the study of Adriatic island flora: Vascular plant species diversity in the Croatian Island of Olib. Natura Croatica $25,25-54$.

Ministry of the Sea, Transport and Infrastructure, 2007: The State program for the protection and use of small, sometimes inhabited and uninhabited islands and the surrounding sea. Retrieved October 10, 2016 from http://www.mppi. hr/userdocsimages /2007/Dr\%C5\%BEavni\%20program\%20 za\%C5\%A1tite\%20i\%20kori\%C5\%A1tenja\%20malih,\%20 povremeno\%20nastanjenih\%20i\%20nenastanjenih\%20otoka\%20i\%20okolnog\%20mora.pdf (in Croatian).

Mucina, L., Bültmann, H., Dierßen, K., Theurillat, J. P., Raus, T., Čarni, A., Šumberová, K., Raus, T., Di Pietro, R., Gavílan García, R., Chytrý, M., Iakushenko, D., Schaminée, J. H. J., Bergmeier, E., Santos Guerra, A., Daniëls, F. J. A., Ermakov, N., Valachovic, M., Pignatti, S., Rodwell, J. S., Pallas, J., Capelo, J., Weber, H. E., Lysenko, T., Solomesh, A., Dimopolous, P., Aguiar, C., Freitag, H., Hennekens, S. M., Tichý, L., 2016: Vegetation of Europe: hierarchical floristic classification system of vascular plant, bryophyte, lichen, and algal communities. Applied Vegetation Science 19, 3-264.
Nikolić, T. (ed.), 2017: Flora Croatica database. Retrieved October 6, 2017 from http://hirc.botanic.hr/fcd.

Nikolić, T., Antonić, O., Alegro, A., Dobrović, I., Bogdanović, S., Liber, Z., Rešetnik, I., 2008: Plant species diversity of Adriatic islands: An introductory survey. Plant Biosystems 142, 435-445.

Nikolić, T., Milović, M., Bogdanović, S., Jasprica, N., 2015: Endemics in flora of Croatia. Alfa d.d., Zagreb (in Croatian).

Nikolić, T., Mitić, B., Boršić, I., 2014: Flora of Croatia. Invasive plants. Alfa d.d., Zagreb (in Croatian).

Nikolić, T., Topić, J. (eds.), 2005: Red Book of Vascular Flora of Croatia. Ministarstvo kulture, Državni zavod za zaštitu prirode, Zagreb (in Croatian).

Official Gazette of the Republic of Croatia, 2013a: Nature Protection Act. Narodne novine 80/13 (in Croatian).

Official Gazette of the Republic of Croatia, 2013b: Regulation on the Ecological Network. Narodne novine 124/13 (in Croatian).

Official Gazette of the Republic of Croatia, 2013c: Ordinance on strictly protected species. Narodne novine 144/13 (in Croatian).

Official Gazette of the Republic of Croatia, 2014: Ordinance on habitat types, habitat map and threatened and rare habitat types. Narodne novine 88/14 (in Croatian).

Official Gazette of the Republic of Croatia, 2015: Regulation amending the Regulation on the Ecological Network. Narodne novine 105/15 (in Croatian).

Pandža, M., Milović, M., 2015: Flora of the islets near Pakoštane (Dalmatia, Croatia). Natura Croatica 24, 19-35.

Pasta, S., Sciberras, A., Sciberras, J., Scuderi, L., 2014: Analysis of the vascular flora of four satellite islets of the Egadi Archipelago (W Sicily), with some notes on their vegetation and fauna. Biodiversity Journal 5, 39-54.

Pignatti, S. 1982: Flora d'Italia 1-3. Edagricole, Bologna.

Pretto, F., Celesti-Grapow, L., Carli, E., Brundu, G., Blasi, C., 2012: Determinants of non-native plant species richness and composition across small Mediterranean islands. Biological Invasions 14, 2559-2572.

Raunkiaer, C., 1934: The life forms of plants and statistical plant geography. Clarendon Press, Oxford.

Rivas-Martínez, S., Sáenz, S. R., Penas, A., 2011: Worldwide bioclimatic classification system. Global Geobotany 1, 1-634.

Russell, B., Glicksman, K., 2015: Recent work on Roman quarries near Korčula and on Brač. Vjesnik za arheologiju i historiju dalmatinsku 108, 223-244.

Skelin, M., Ljubičić, I., Skelin, I., Vitasović Kosić, I., Bogdanović, S., 2014: The Flora of Zečevo (Hvar Archipelago, Croatia). Agriculturae Conspectus Scientificus 79, 85-91.

Solarić, M., Solarić, N., 2009: Lumbarda Psephisma, the oldest document about the division of land parcels in Croatia from the beginning of the $4^{\text {th }}$ or $3^{\text {rd }}$ century BC. Kartografija i Geoinformacije 8, 78-88.

Stančić, Z., 2008: Ass. Eleocharitetum palustris Schennikow 1919 in Croatia. Natura Croatica 17, 335-355.

Šilc, U., Čarni, A., 2012: Conspectus of vegetation syntaxa in Slovenia. Hacquetia 11, 113-164.

Škvorc, Ž., Jasprica, N., Alegro, A., Kovačić, S., Franjić, J., Krstonošić, D., Vraneša, A., Čarni, A., 2017: Vegetation of Croatia: Phytosociological classification of the high-rank syntaxa. Acta Botanica Croatica 76, 200-224.

Šumberová, K., 2011: MCC06 Eleocharitetum palustris Savič 1926. In: Chytrý M. (ed.), Vegetation of the Czech Republic 3. Aquatic and wetland vegetation, 465-469. Academia, Praha (in Czech).

Trinajstić, I. (ed.), 1975-1986: Analytical flora of Yugoslavia 2. Institut za botaniku Sveučilišta u Zagrebu, Zagreb (in Croatian). 
Tutin, T. G., Burges, N. A., Chater, A. O., Edmondson, J. R. E., Heywood, V. H., Moore, D. M., Valentine, D. H., Walters, S. M., Webb, D. A. (eds.), 1993: Flora Europaea 1 ( $2^{\text {nd }}$ ed.). Cambridge University Press, Cambridge.

Tutin, T. G., Heywood, V. H., Burges, N. A., Moore, D. M., Valentine, D. H., Walters, S. M., Webb, D. A. (eds.), 1968-1980: Flora Europaea 2-5. Cambridge University Press, Cambridge.

Tzonev, R. T., Dimitrov, M. A., Roussakova, V. H., 2009: Syntaxa according to the Braun-Blanquet approach in Bulgaria. Phytologia Balcanica 15, 209-233.

Valaoras, G., 2014: Biodiversity. In: Cao, G., Orrù, R. (eds.), Current Environmental Issues and Challenges, 207-216. Springer Science+Bussines Media, Dordrecht.

\section{Appendix 1.}

\section{Syntaxa quoted in the text and tables (in alphabetical order), but not in scheme}

Adiantetea Br.-Bl. et al. 1952

Ammophiletea Br.-Bl. et Tx. ex Westhoff et al. 1946

Artemisietea vulgaris Lohmeyer et al. in Tx. ex von Rochow 1951 Asplenietea trichomanis (Br.-Bl. in Meier et Br.-Bl. 1934) Oberd. 1977

Carpino-Fagetea sylvaticae Jakucs ex Passarge 1968

Epilobietea angustifolii Tx. et Preising ex von Rochow 1951

Festuco-Brometea Br.-Bl. et Tx. ex Soo 1947

Isoëto-Nanojuncetea Br.-Bl. et Tx. in Br.-Bl. et al. 1952

Juncetea maritimi Br.-Bl. in Br.-Bl. et al. 1952

Ononido-Rosmarinetea Br.-Bl. in A. Bolòs y Vayreda 1950

Quercetea pubescentis Doing-Kraft ex Scamoni et Passarge 1959

Salicornietea fruticosae Br.-Bl. et Tx. ex A. Bolòs y Vayreda et O. de Bolòs in A. Bolòs y Vayreda 1950
Vela, E., 2002: Biodiversité des milieux ouverts en région méditerranéenne. Le cas de la végétation des pelouses du Luberon (Provence Calcaire). Thèse de doctorat. Ecologie, Université de droit, d'économie et des sciences d'Aix Marseille (Aix Marseille III), Maseille.

Weber, H. E., Moravec, J., Theurillat, J. P., 2000: International code of phytosociological nomenclature. Journal of Vegetation Science 11, 739-768.

Whisenant, S. G., Thurow, T. L., Maranz, S. J., 1995: Initiating autogenic restoration on shallow semiarid sites. Restoration Ecology $3,61-67$. 